UDC $811.111^{\prime} 42$

\title{
PRAGMATIC AND FUNCTIONAL PECULIARITIES OF EUPHEMISMS FOR DISEASES, DEATH AND DYING IN THE ENGLISH MASS-MEDIA DISCOURSE
}

\author{
S. Baranova, PhD in Philology, Associate Professor \\ iD ORCID: 0000-0001-9425-9774 \\ K. Pletenko, Student \\ Sumy State University, \\ 2, Rymskogo-Korsakova St., Sumy, 40007, Ukraine \\ E-mail: s.baranova@gf.sumdu.edu.ua; kri.volfy@gmail.com
}

The article describes euphemisation processes in English for the themes of diseases, death and dying on the materials of the mass-media discourse. It shows a detailed analysis of different lexical units of substituting nature to find out the reasons and causes of active language euphemisation. Nowadays euphemistic processes are wide spread, but the aim of their usage has changed from the times of ancient people which are thought to have been afraid of inexplicable things and using straightforward terms dealing with such subjects. Special attention is paid to finding the connections between euphemisms and people's concepts and way of thinking. The analysis also stresses the timeless nature of this linguistic phenomenon, in which psychological, religious and social interdictions coexist.

Keywords: euphemism, language universal, substitution, pragmatic factors, functional features.

DOI: 10.21272/ Ftrk.2018.10(1)-02

Introduction. Mass media play a significant role in the modern life of society, therefore, the methods, or in other words, the channels that help to receive information, greatly influence the formation of a worldview of a separate individual, as well as the general community. Well-chosen for the needs of the situation words or expressions can cause a resonance in society because of a trivial event, and alleviate the wave of disagreement as a result of loud controversy. Euphemisation is one of the ways for concealing the negative connotation of the message through its functional features and considering it as a language universal, that is, a characteristic phenomenon for many folks. Euphemisms are in active daily use, so their use is transferred from the sphere of household to other important spheres of life.

In general, in linguistics, there are two views on the phenomenon of euphemisms: narrow (substitutional) and broad (pragmatic) [1, p. 10]. In the Longman Dictionary of Contemporary English we can discover, that a euphemism from the linguistic point of view is a polite word or expression that can be used instead of a more direct one to avoid shocking or upsetting someone [9]. The generalized definition of euphemism can be considered the term used to denote a linguistic phenomenon that comes to the language due to extra-linguistic reasons (cultural, social or religious dogma), which serve as taboo avoidance and concealment of certain information for the speaker's interests, paying attention to the feelings and emotions of his or her target audience. In other words, it is a substitute for a word, phrase or word-combination with negative connotations for a speaker or a listener to a similar unit, but with a neutral or (more) positive meaning.

The relevance of the study is justified by the necessity of a comprehensive euphemistic study, which contributes not only to the knowledge of a particular language system, but also to deepening the understanding of concept making processes and further verbalization of its speech and language implementation.

The objective of the article is to describe the main reasons for euphemistic use and the way of these units functioning in the English mass-media discourse.

(C) Baranova S., Pletenko K., 2018

«Філологічні трактати», Том 10, № 1 ' 2018 
The objective implies the following tasks of the research:

1) to define the general peculiarities of euphemisms in the analyzed discourse;

2) to study the subdivisions of euphemisms for diseases, death and dying;

3) to analyze the use of euphemisms on the materials of the English mass-media discourse;

4) to formulate the main pragmatic and functional features of euphemisms.

The subject matter is the variety of euphemisms for diseases, death and dying in the English media texts of the beginning of the XXI century.

The specific topic of the study is pragmatics and functional basis of euphemisation within the English media discourse.

Results of the research. In the sphere of English-language media, the role of euphemisms is to prevent and overcome racism or any other discriminatory processes connected with gender, age, social life, etc. That is, they are generally used in the areas of education, religion, interethnic and international relations, economical issues (for example, low-income). These substitutes are found in topics describing the problems among representatives of sexual minorities or vulnerable groups of the population. The euphemisms of mass-media discourse can be also divided into some subgroups as for their stylistic and semantic peculiarities, so we can distinguish the following ones: euphemisms for diseases and deaths, supernatural forces or religious concepts, parts of the human body and various processes of life, including relationships between men and women, substitutes for economic, military, political sphere.

The field of health has always been the source of a large number of euphemisms. From ancient times it was believed that the direct naming of illnesses could lead to distress for the speaker or his family, and the ailments were also considered a manifestation of supernatural and mystical. What causes a person's fear or anxiety becomes an object of euphemisation in order to achieve a psychological comfort. So, for example, the cancer substitutions in English have become Big C, long/prolonged/incurable illness, CA: «... 'We've forgotten way beyond the time when cancer was one thing. But I'm not sure that the big $\boldsymbol{C}$ has gone away,' said Harold Burstein, MD, a medical oncologist at the Dana-Farber Cancer Institute in Boston»(Medscape-8, 08.04.2017). In other words cancer can be also named as the king of terrors, what shows the society's attitude to the illness and even a kind of phobia: "...'The emperor of all maladies, the king of terrors'. This phrase was used by a $19^{\text {th }}$ century surgeon to describe cancer. More than a century later, the description unfortunately still applies» (Motley Fool, 12.10.2017).

The phrase «health reasons» can conceal any disease, from the common cold to syphilis or tuberculosis, so the reason why it is often used in the media is its general informative nature, for example: «Security Minister Leonid Pasechnik said on Friday that he was taking over after Plotnitsky resigned for health reasons. There was no versification of the claim from Plotnitsky» (Voice of America, 24.11.2017). Other general health substitutes are the words discomfort and uncomfortable physical condition: «A female passenger arriving from Sao Paulo was taken to a hospital when starting to show physical signs of discomfort while being searched at OR Tambo International Airport on Monday morning» (Kempton Express, 23.11.2017), "Following a six week disappearance North Korea's leader has previously admitted suffering from an uncomfortable physical condition» (Express.co.uk., 20.11.2017). In the examples above, euphemisms are used to conceal more detailed information, but reflect the presence of certain health problems, albeit veiled.

Some euphemisms are metaphorical in nature, therefore, without the precise knowledge of their meaning, it's difficult to guess what is being discussed, therefore, such phrases are a good verbal camouflage: «Mistakes happen; children feel under the weather or have a bad evening beforehand. This does not mean that teachers are not working as hard as possible» (BBC News, 01.02.2015), where the underlined euphemism is used to denote short-term ailments.

However, not only the sphere of physical health becomes euphemistic, but also the problematics of the mental state, too. The development of society has contributed to the 
consideration of psychological ailments as more severe in comparison with physical, which has become the key factor to the widespread silence in this area. Since the behavior of mentally ill people can often appear beyond the generally accepted norms, eccentric, funny (as a manifestation of the psychological reaction of protection against obscure external factors that may endanger the threat), so there are many substitutes with the word funny in its composition: funny in the head, wacky, funny farm. On the other hand, there are euphemisms that show the human fear of losing control of oneself and of their minds: out of one's mind, mad, crazy, losing one's mind. However, at this stage, they lost their first vivid euphemistic meaning, and therefore began to be replaced by the substitutes like mentally challenged, of unsound mental condition: «Police in Murewa have arrested a suspected mentally-challenged woman who fatally struck her blind sister using a hoe» (News Day, 24.11.2017).

The English-language mass-media discourse is also characterized with a high level of indirect verbal nominations to denote death and attributes associated with it, as it also manages the human factor and norms of modern etiquette and morals. In this case directness is considered a manifestation of rudeness and negligence, which at the same time can cause even more pain. Now characteristic units here are euphemistic expressions that describe this process as a «departure» to distant countries, a flight to heaven or just a fall: pass it, pass it, pass it to the next world, go to Heaven, leave the hand of the living, go to a better place, go west, return to ashes and sleep away. For this sphere of euphemisation, metaphorization is also a characteristic feature. This statement can be proved with the help of the following expressions - go the way of all flesh, meet one's maker : "You're not in control of life, and therefore you will go the way of all flesh, so you should enjoy each and every blessed day» (Statesville Record \& Landmark, 04.11.2017), "Horror of debt is particularly marked in the elderly, perhaps out of an ancient feeling that one should not meet one's maker with a negative balance sheet» (The Guardian, 25.08.2016). It's necessary to mention, that go the way of all flesh is also an example of allusion, because it appears in a poem by John Webster, a contemporary of Shakespeare, and is the title of a novel by Samuel Butler in 1902.

Another kind of diseases, which are strongly substituted in different times and communities, are illnesses connected with sexual life of people. For example, the expression "venereal disease», which is generalized notion and can be used like a euphemism itself, has some other substitutes: French disease/pox, affliction of the loins, bad disorder, blue fever, etc.: «Even the appearance of a former prostitute played by Amy Dawson (Game of Thrones) who is stricken with the "French pox» fails to elicit anyone's genuine sympathy» (The Australian, 22.08.2017).

There are euphemisms whose habitat is a working environment of a certain professional orientation, so such expressions often refer to professional jargon vocabulary, which makes it more characteristic of written expression in the mass media because of its possible obscurity for other strata of society. For example, the theatre actors say about the death of their colleague with the help of the substitute a last curtain call, which shows the connection with the usual theatrical terminology. "Non-beating-heart donors provide kidneys, livers and other organs, but until now it has not been possible to use the heart because of concerns it would suffer damage» (BBC News, 26.03.2015) . This example of the medical sector brightly shows the associativity of the approach to the formation of euphemistic rotations.

As a boxing imagery, count is also used like a euphemism for death. But the «long count», though rarer, shows greater knowledge of the sport. «To put someone for the count» is to make unconscious rather than to kill. «To count the daises» can be understood like to be dead.

However, the use of euphemism is not always well-considered and successful. For example, Phyllis Sommer in a speech at «TED Talks» shared her story about the loss of her son who died of leukemia. She noted the huge amount of euphemisms came into her life to support the combat spirit in this difficult time for her and the closest. She was called as a 
mother who «lost her child», about what her friend replied as follows: «His parents have not lost their child, they would never, could never be so careless» [5]. This example is the evidence that euphemisms in the role of concealers of true expressiveness sometimes seem to devalue the importance or real emotional spectrum of the event, which deprives people of their ability to reveal their human qualities, to empathize with someone else's grief, to support others in a difficult moment.

Euphemistic substitutes of the word kill often become the idioms of the verb to put (put a person's lights out, put daylight through, put against a wall, put to sleep): «But due to a change in the way the charity funds treatment for sick animals, Mrs. Bakewell said some owners would be forced to have their pets put to sleep because they would be unable to afford treatment» (Nottingham Post, 06.11.2017). Such lexical units, as self-deliverance, self-violence, self-execution are used to replace the phrase «commit a suicide».

«Execution» and «capital punishment» are often used in the media, where the first substitute passes the way this act is carried out, as opposed to the second example: «An Arizona death row inmate's Supreme Court case could end to capital punishment in Texas and across the country" (Chron.com, November 23, 2017). There is also a more metaphorical expression on the notation of the penalty - the verbal phrase «to silence someone». Execution itself is a carrying out of a judicial order of punishment. This term is extended from the notion of executing a sentence of death to the actual killing of a person. Among synonyms and related lexical units the following should be mentioned: burning alive, demembration (the crime of maliciously severing a limb from the body of a person), drawing and quartering (a part of the grisly penalty anciently ordained in England (1283) for the crime of treason), electric cure, pelvic exenteration (a radical surgical treatment that removes all organs from a person's pelvic cavity), lapidation (a method of capital punishment whereby a group throws stones at a person until they die). These words show the diachronic development of the notion and the historically and culturally characteristic features of different epochs.

Having analyzed the above presented examples, among the pragmatic factors of euphemistic processes in this discourse the following should be noted:

1) the desire to avoid any kind of taboo: to feel under water (to be ill), to pass away (to die);

2) the principle of polite attitude (refers to «mitigating» of discriminatory manifestations of any kind): visually challenged (blind), indigestion (over-eating);

3 ) intention to achieve the communicative comfort between all the participants of the communicative act;

4) manipulative influence (forming a society's vision of important or relevant events and pressing issues): conflict (war), insurgent groups (terrorists);

5) the desire to hide the negative message's content: economically disadvantaged (poor), in substandard housing (in a slum).

On the basis of the pragmatic features of the euphemistic use, it is necessary to highlight the following functions of substitutes:

1) masking, which is inherent in all euphemisms and is aimed at concealing certain aspects of the primary content of the message;

2) preventive, consisting in prevention of a misunderstanding between the participants of the communicative act and the image of one's party's feelings through the use of the taboo: self-deliverance (commit a suicide);

3) manipulative, helping to influence the value priorities of the recipients or their judgmental judgments: elevated interrogation expediations (torture);

4) grinding, which reduces the previously expressive bright expressiveness of the expression, makes it more or even neutral: average-looking (ugly), to go the way of all flesh (to die).

Conclusions. A euphemism is a linguistic phenomenon, which is a vivid example of bilateral interaction between processes of society's development and its ideological principles. With the passage of time and changes in the vital, moral and social orientations 
of the community, the use of euphemistic structures has also been modernized, what we can prove by its large synonymic system. People always feel uncomfortable talking about their health problems, death of someone (in the household these aspects can be freely spoken about, but not so open in the public). It's even accustomed to use the secondary nomination for these aspects of life to sound more respectful, reliable and in some way poetic and scientific, because there are lots of euphemisms which are metaphoric in their kind and contain words of foreign origin or some terms to complicate the understanding of what is meant from the first time people have heard or read the expression.

\section{ПРАГМАТИКО-ФУНКЦИОНАЛЬНЫЕ ОСОБЕННОСТИ ЭВФЕМИЗМОВ ДЛЯ БОЛЕЗНЕЙ, СМЕРТИ И ЕЕ АТРИБУТОВ В АНГЛИЙСКОМ МАСС-МЕДИЙНОМ ДИСКУРСЕ}

С. В. Баранова, канд. филол. наук, доцент;

К. Плетенко, студент

Сумский государственный университет,

ул. Римского-Корсакова, 2, г. Сумыл, 40007, Украина

E-mail: s.baranova@gf.sumdu.edu.ua; kri.volfy@gmail.com

В статье описываются проиессы эвфемизации на базе английского языка, которые касаются тем проблем со здоровьем, а также смерти в различных ее аспектах на материалах масс-медийного дискурса. Показан детальный анализ различных лексических единиц субститутивной природы с иелью выяснить причины и факторы активного процесса языковой эвфемизации. B наши дни эвфемизационные процессы имеют иирокое распространение, но цель их применения изменилась со времен древних людей, которые, как считается, боялись необъяснимого, а также прямого наименования такого рода понятий. Особое внимание уделяется обнаружению связей между эвфемизмами и кониептами людей, а также их способом мышления. Данный анализ также подчеркивает универсальный характер этого языкового феномена, в котором сосуществуют психологические, религиозные и сочиильные запретьл.

Ключевые слова: эвфемизм, языковая универсалия, субститут, прагматические факторы, функииональные особенности

\section{ПРАГМАТИКО-ФУНКЦІОНАЛЬНІ ОСОБЛИВОСТІ ЕВФЕМІЗМІВ ДЛЯ ХВОРОБ, СМЕРТІ ТА ЇЇ АТРИБУТІВ У АНГЛІЙСЬКОМУ МАС-МЕДІЙНОМУ ДИСКУРСІ}

С. В. Баранова, кан. філол. наук, дочент;

К. Плетенко, студент

Сумський державний університет,

вул. Римського-Корсакова, 2, м. Суми, 40007, Украӥна

E-mail: s.baranova@gf.sumdu.edu.ua; kri.volfy@gmail.com

У статті описуються прочеси евфемізачії на базі англійської мови, які стосуються тем проблем зі здоров'ям, а також смерті в різних ії аспектах на матеріалах мас-медійного дискурсу. У ній показаний детальний аналіз різних лексичних одиниць субститутивної природи з метою з'ясувати причини і фактори активного процесу мовної евфемізачії. У наші дні евфемізаційні прочеси мають значне поширення, але мета їх застосування змінилася з часів стародавніх людей, які, як вважається, боялися нез'ясовного, а також прямого найменування такого роду понять. Особлива увага приділяється виявленню зв'язків між евфемізмами і концептами людей, а також їх способом мислення. Даний аналіз також підкреслюе універсальний характер цього мовного феномена, у якому співіснують психологічні, релігійні та соиіальні заборони.

Ключові слова: евфемізм, мовна універсалія, субститут, прагматичні чинники, функиіональні особливості 


\section{REFERENCES}

1. Reshetarova, I. V. (2010). Zasoby evfemii v masmediinomu dyskursi pochatku XXI stolittia [Means of euphemism in the media discourse of the early twenty-first century]. Extended abstract of candidate's thesis. Donetsk, Ukraine.

2. Game-Changing Cancer Drug Innovations Being Developed Right Now : Could these revolutionary therapies turn the tide in the fight against cancer? (12. October 2017). Motley Fool. Retrieved 29.11.2017 from https://www.fool.com/investing/2017/10/12/5-game-changing-cancer-drug-innovations-being-deve.aspx.

3. Animal lovers could be forced to put beloved pets down under new PDSA rules. (November 06, 2017). Nottingham Post. Retrieved 30.11.2017 from http://www.nottinghampost.com/news/nottingham-news/animallovers-could-forced-put-728539

4. Balochistan journalists caught «between the stick and the gun» (. November 26, 2017). BBC News. Retrieved 30.11.2017 from http://www.bbc.com/news/world-asia-42086695

5. Sommer, Phyllis. (2017). Dead is dead: euphemism and the power of words. TED Talks. Retrieved 30.11.2017 from https://www.youtube.com/watch?v=UUqr4P7P3gM

6. Harlots exposes life of $18^{\text {th }}$-century madams and brothels. (August 22, 2017). The Australian. Retrieved 30.11.2017 from http://www.theaustralian.com.au/arts/television/harlots-exposes-life-of-18thcenturymadams-and-brothels/news-story/1e4b7b6e38fc3f014173b34b500e38ce

7. Joe Hudson Column: Local man suffers head trauma [Electronic resource]. (November 04, 2017). Statesville Record \& Landmark. Retrieved 30.11.2017 from http://www.statesville.com/community/joe-hudson-columnlocal-man-suffers-head-trauma/article_d006960c-bfce-11e7-a482-c3c3d7986dc4.html

8. Kim Jong-un 'gravely' ill? Lack of North Korea missile tests spark rumours about dictator. (November 20, 2017). Express.co.uk. Retrieved 30.11.2017 from https://www.express.co.uk/news/world/881751/Kim-Jongun-ill-health-North-Korea-missile-test-weight-weapons

9. Longman Dictionary of Contemporary English. (2017). Retrieved 28.11.2017 from https://www.ldoceonline.com/dictionary/euphemism

10. Can We Stop Calling Cancer the 'Big C'? (April 08, 2016). Medscape-8. Retrieved30.11.2017 from https://www.medscape.com/viewarticle/861712

11. Mentally-challenged woman bludgeons blind sister to death (November 24, 2017). News Day. Retrieved 30.11.2017 from https://www.newsday.co.zw/2017/11/mentally-challenged-woman-bludgeons-blind-sisterdeath/

12. Nicky Morgan announces «war on illiteracy and innumeracy». (February 01, 2015). BBC News. Retrieved 30.11.2017 from http://www.bbc.com/news/uk-31079515

13. Separatist Leader Says He Is Taking Power in Ukraine's Luhansk Region. (November 24, 2017). Voice of America. Retrieved 30.11.2017 from https://www.voanews.com/a/ukraine-regional-minister-says-he-is-newleader-of-luhansk/4135783.html

14. Supreme Court case could be death knell for capital punishment. (November 23, 2017). Retrieved 30.11.2017 from http://www.chron.com/news/houston-texas/article/Supreme-Court-case-could-kill-capital-punishment12380271.php

15. Halifax men get four months for prison assault of accused killer Dennis Oland. (23.11.2017). The Guardian Retrieved 30.11.2017 from http://www.theguardian.pe.ca/news/two-men-who-assaulted-dennis-oland-inprison-to-be-sentenced-today-164259/

16. Woman's 'discomfort' leads to cocaine bullet find. (November 23, 2017). Kempton Express. Retrieved 30.11.2017 from https://kemptonexpress.co.za/161465/womans-discomfort-leads-to-cocaine-bullets/

\section{СПИСОК ВИКОРИСТАНИХ ДЖЕРЕЛ}

1. Решетарова I. В. Засоби евфемії в масмедійному дискурсі початку XXI століття : автореф. дис. ... на здобуття наук. ступеня канд. філол. наук : спец. 10.02.15 «Загальне мовознавство» / І. В. Решетарова. Донецьк, 2010. - $21 \mathrm{c.}$

2. Game-Changing Cancer Drug Innovations Being Developed Right Now : Could these revolutionary therapies turn the tide in the fight against cancer? [Electronic resource] // Motley Fool. - 12. October 2017. - Access mode : https://www.fool.com/investing/2017/10/12/5-game-changing-cancer-drug-innovations-beingdeve.aspx. - Accessed : 29.11.2017.

3. Animal lovers could be forced to put beloved pets down under new PDSA rules [Electronic resource] / Nottingham Post. - 06. November 2017. - Access mode: http://www.nottinghampost.com/news/nottinghamnews/animal-lovers-could-forced-put-728539. - Accessed : 30.11.2017.

4. Balochistan journalists caught «between the stick and the gun» [Electronic resource] / BBC News. November 26, 2017. - Access mode: http://www.bbc.com/news/world-asia-42086695. - Accessed : 30.11.2017.

5. Dead is dead : euphemism and the power of words [Electronic resource] / TED Talks [by Phyllis Sommer]. Access mode: https://www.youtube.com/watch?v=UUqr4P7P3gM. - Accessed : 30.11.2017.

6. Harlots exposes life of $18^{\text {th }}$-century madams and brothels [Electronic resource] // The Australian. - 22. August 2017. - Access mode : http://www.theaustralian.com.au/arts/television/harlots-exposes-life-of-18thcenturymadams-and-brothels/news-story/1e4b7b6e38fc3f014173b34b500e38ce. - Accessed : 30.11.2017.

7. Joe Hudson Column: Local man suffers head trauma [Electronic resource] // Statesville Record \& Landmark. - November 04, 2017. - Access mode : http://www.statesville.com/community/joe-hudson-column-localman-suffers-head-trauma/article_d006960c-bfce-11e7-a482-c3c3d7986dc4.html. — Accessed : 30.11.2017. 
8. Kim Jong-un 'gravely' ill? Lack of North Korea missile tests spark rumours about dictator [Electronic resource] // Express.co.uk. -November 20, 2017. - Access mode : https://www.express.co.uk /news/world/881751/Kim-Jong-un-ill-health-North-Korea-missile-test-weight-weapons. _ - Accessed 30.11.2017.

9. Longman Dictionary of Contemporary English [Electronic resource]. - Access mode : https://www.ldoceonline.com/dictionary/euphemism. - Accessed : 28.11.2017.

10. Can We Stop Calling Cancer the 'Big C'? [Electronic resource] // Medscape-8. -April 08, 2016. - Access mode: https://www.medscape.com/viewarticle/861712. - Accessed : 30.11.2017.

11. Mentally-challenged woman bludgeons blind sister to death [Electronic resource] // News Day. -November 24, 2017. - Access mode : https://www.newsday.co.zw/2017/11/mentally-challenged-woman-bludgeonsblind-sister-death/. - Accessed : 30.11.2017.

12. Nicky Morgan announces «war on illiteracy and innumeracy» [Electronic resource] // BBC News. -February 01, 2015. - Access mode : http://www.bbc.com/news/uk-31079515. - Accessed : 30.11.2017

13. Separatist Leader Says He Is Taking Power in Ukraine's Luhansk Region [Electronic resource] // Voice of America. -November 24, 2017. - Access mode : https://www.voanews.com/a/ukraine-regional-minister-sayshe-is-new-leader-of-luhansk/4135783.html. - Accessed : 30.11.2017.

14. Supreme Court case could be death knell for capital punishment [Electronic resource] // Chron.com. November 23, 2017. - Access mode : http://www.chron.com/news/houston-texas/article/Supreme-Court-casecould-kill-capital-punishment-12380271.php. - Accessed : 30.11.2017.

15. Halifax men get four months for prison assault of accused killer Dennis Oland [Electronic resource] // The Guardian. -November 23, 2017. - Access mode : http://www.theguardian.pe.ca/news/two-men-whoassaulted-dennis-oland-in-prison-to-be-sentenced-today-164259/. — Accessed : 30.11.2017.

16. Woman's 'discomfort' leads to cocaine bullet find [Electronic resource] // Kempton Express. -November 23 , 2017. - Access mode : https://kemptonexpress.co.za/161465/womans-discomfort-leads-to-cocaine-bullets/. Accessed : 30.11.2017.

Received: 30 January 2018 